\title{
The Frequency and Voltage Stability Analysis of Hu-liao DC Project in Islanding Sending End System
}

\author{
Yundong Song ${ }^{1, a}$, Yuanqing $\mathrm{Wu}^{2, b}$,Yisong Zhao ${ }^{1}$, Qiang Zhang ${ }^{1}$, Chunfang \\ Zhao $^{3}$, Jingwei Yuan ${ }^{1}$,Zaiming $\mathrm{Yu}^{1}$, Ruitong, Liu ${ }^{1}$, Chunmei Liu $^{2}$ \\ ${ }^{1}$ Electric Power Research Institute, State Grid Liaoning Electric Power Co., Ltd. Shenyang, 110006, \\ China \\ ${ }^{2}$ College of New Energy, Bohai University Jinzhou, 121013, China \\ ${ }^{3}$ TBEA Shenyang Transformer Group Co., Ltd.Shenyang, 110025, China \\ asongyundong@126.com, bwuyuanqing123@163.com
}

Keywords: Islanding System; DC Project; DC Power Delivery; Mono-polar Blocking

\begin{abstract}
When the circuit breakers between Yimin one, two and Yimin three period, the sending end system consisting of six 600MW generators of Hu-liao DC project will operate islanding. In the paper, three operation modes of the power dispatching and production department concerned were simulated, which the change of the DC plan external-transmission, DC project occur monopole ESOF and the sending-end occur three-phase short circuit fault. The simulation results shown the coordinated control strategy of DC project and islanding sending end system can meet the system frequency and voltage and DC power transmission requirements. The control strategy can provide a reference for the power dispatching and production department.
\end{abstract}

\section{Introduction}

With the world's first HVDC transmission line was created by the Asea (ABB Group) in 1954, which is used to Connect Sweden land and Gotland Island, HVDC has been widely used in the world. Since the distribution of China's energy production area and China's energy demand area are extremely unbalanced. The exploitable water resources are mainly distributed on the southwestern provinces, coal resources concentrate in Shanxi and Inner Mongolia, a seriously energy shortage along the Beijing-Guangzhou railway and its eastern economical developed area. At present, it has built up a national pattern of energy distribution, which are that electricity transmission from west to east, coal transmission from the north to south as in [1][2][3][4]. Therefore, the HVDC technology has a considerable development, because it's suitable for a long-distance transmission, the electricity sending of large capacity, asynchronous networking, easy control and regulation.

The DC transmission project of hydropower or thermal power plants, which are away from the main grid, the sending end AC system has the possibility of island operation. Because traditional HVDC systems engineering needs on both ends of the auxiliary AC converter valve commutation, and the power regulation of the thermal power unit is slow, DC power regulation of it is fast, therefore, it's necessary to solve the DC project, which is under the island operation condition, and sending-end system coordinated control strategy, so that, it can make sure the frequency and the voltage of the sending end system be stable as in [5][6][7][8] [9] .

The power dispatching and production department concern many relevant contents about the island operation, there are three main researches:

(1) When the DC plan of external-transmission power changes, the study of the control strategy about the DC project and sending-end units coordinating;

(2) When DC project occur monopole ESOF, the study of the control strategy about the DC project and sending-end units coordinating;

(3) When the sending-ednd system occurs three-phase short circuit fault, the study of the control strategy about the DC project and sending-end units coordinating.

In the paper, the frequency and the voltage of Hu-Liao DC sending-end system were researched, 
under the conditions of the DC sending-end island operation.

\section{Simulation Models Establishing}

Hu-Liao HVDC rectifier rated DC voltage is $\pm 500 \mathrm{kV}$, rated DC current is 3kA, and rated transmission power is 3000MW. As in [10], the HVDC protect model were obtained.

\section{A.Sending end system modeling}

Rectifier side AC system consists of six 600MW generation units, including two Baorixile plants in the Hulunbeier area, Ewenke plant and Yimin stage-III plant, the line connected Yimin stage-III plant and Yimin stage-one and stage-two between the AC system was split, and would be formed to Hu-Liao HVDC island.

Since the main research is the stability issues of the Hu-Liao sending end system, therefore, the ability to deliver end speed units should try to consider detailed and practical, A seven-brand detailed model of six generator units build in the PSCAD simulation platform, and also build excitation system, PSS system and governor system.

\section{B.Equivalence and modeling of the receiving system}

Using the "EPRIE" method achieves equivalence of the northeastern grid by the 2010 winter heavy load model. The equivalent grid reserves the $500 \mathrm{kV}$ busbar from Fengtun transformer substation, $500 \mathrm{kV}$ busbar from Daqing, $500 \mathrm{kV}$ converter busbar from the Mujia. Before and after the equivalence, the current of the main lines in the system are coinciding. For the network before and after equivalence, doing the three-phase and single-phase short circuit current calculation of the commutation bus respectively, the results prove that the commutation bus short circuit current is consistent.

\section{The System Stability Under DC Plan of External-transmission Changing}

\section{A.The control strategy $D C$ power increase/downhill}

(1) According to speed of $200 \mathrm{MW} / \mathrm{min}$ increase/decrease the output of the generator and DC external-transmission power;

(2) If the frequency of sending end system does not exceed the current frequency response range, according to speed of $200 \mathrm{MW} / \mathrm{min}$ continue to increase/decrease transmission power;

(3) If the frequency is beyond the range of the sending end system's frequency response, needs to be changed DC transmission power increase or decrease speed, according to the frequency rising/fall corresponding in the sending end system;

(4) When the DC power delivery to reach the planned value, stop sending end generator output and DC outgoing power increases/decreases.

\section{B.The Research of stability system}

- System operation

(1) The DC power fall 300MW in the six generation units ending end system

The system load flow of Hu-Liao 6 generators system trend shown in Fig. 1. The sending ending sent power is $3016 \mathrm{MW}$, and the output of Hulunbeir power plant is $1100 \mathrm{MW}$, the output of Evenki power plant is $778 \mathrm{MW}$, the output of Yimin power plant III is $1138 \mathrm{MW}$. The DC transmission power is $3000 \mathrm{MW}$. 


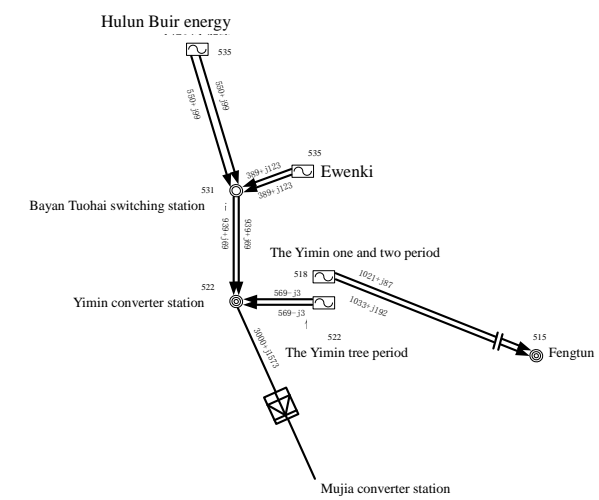

Figure.1. The load flow of six units system

The frequency of ending system was stable, after 5s, DC power fall began, and stopped at the transmission power reached 2700MW. Large fluctuations of the Baorixile and Yimin generators happened in the $5 \mathrm{~s}$, which fluctuations trends is opposite with system frequency fluctuation. As shown, generator has a frequency regulation.

(2)The DC power fall 300MW in the five generation units ending end system

The system load flow of Hu-Liao 5 generation units' system trend shown in Fig. 2. The sending ending sent power is $2710 \mathrm{MW}$, and the output of Hulunbeir power plant is 502MW, the output of Evenki power plant is $1070 \mathrm{MW}$, the output of Yimin power plant III is $1138 \mathrm{MW}$. The DC transmission power is 2700MW.

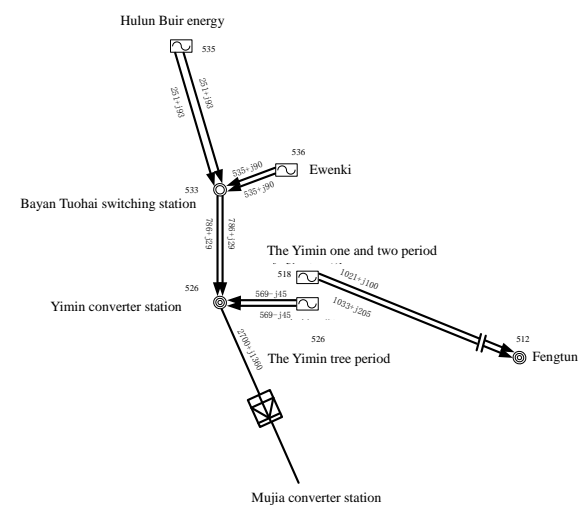

Figure.2. The load flow of five units system

The frequency of ending system was stable, after 5s, DC power fall began, and stopped at the transmission power reached 2400MW.

(3)The DC power increase 300MW in the five generation units ending end system

The frequency of ending system was stable, after 5s, DC power increase began, and stopped at the transmission power reached 3000MW.

(4) The DC power increase 300MW in the four generation units ending end system

The system load flow of Hu-Liao 4 generation units system trend shown in Fig. 3. The sending ending sent power is $2110 \mathrm{MW}$, and the output of Hulunbeir power plant is 502MW, the output of Evenki power plant is 1068MW, the output of Yimin power plant III is 540MW. The DC transmission power is $2100 \mathrm{MW}$. 


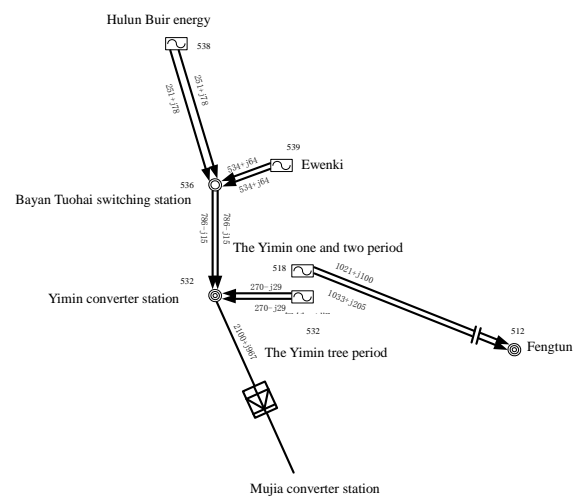

Figure.3. The load flow of four units system

The frequency of ending system was stable, after 15s, DC power increase began, and stopped at the transmission power reached 2400MW.

(5)The DC power fall 300MW in the four generation units ending end system

The frequency of ending system was stable, after 15s, DC power fall began, and stopped at the transmission power reached 1800MW.

- Result analysis

(1)The result of simulation

The frequency curves of five operation modes above-mentioned were shown in Fig. 4-8. The specific ranges of frequency were shown in Table I . The voltage range of the sending end system and DC project were shown in Table II.

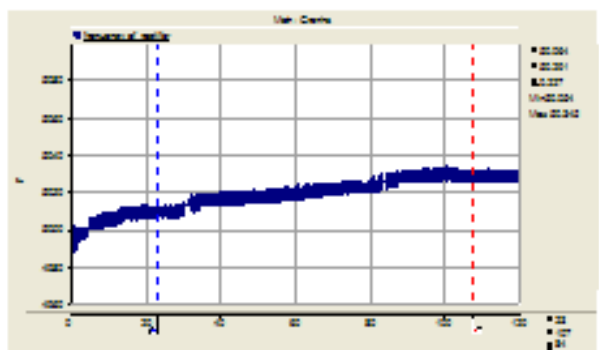

Figure.4. The frequency of the DC power fall 300MW in the six generation units ending end system

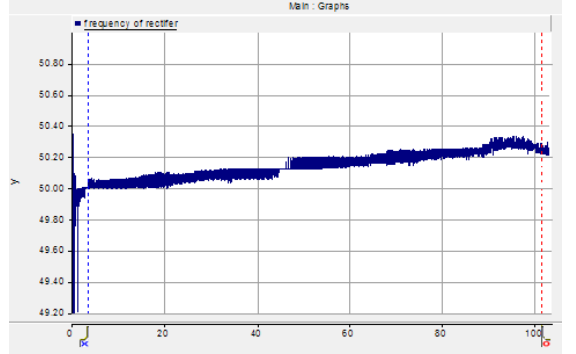

Figure.5. The frequency of the DC power fall 300MW in the five generation units ending end system

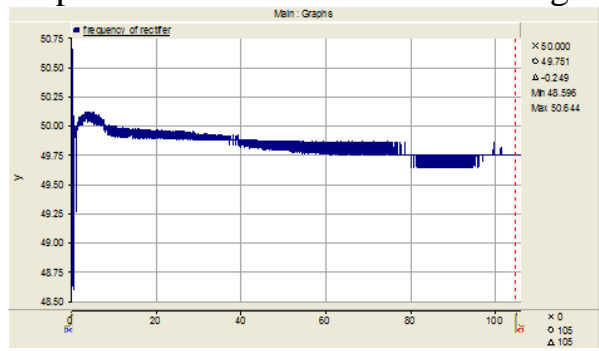

Figure.6. The frequency of the DC power increase 300MW in the five generation units ending end system 


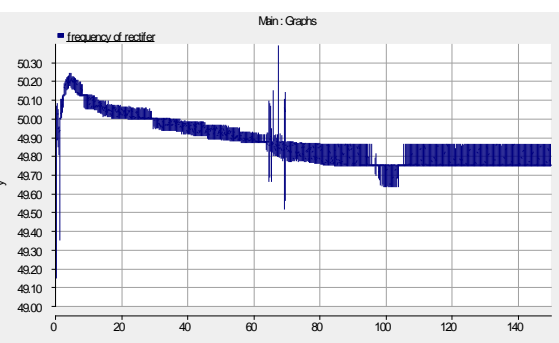

Figure.7. The frequency of the DC power increase 300MW in the four generation units ending end system

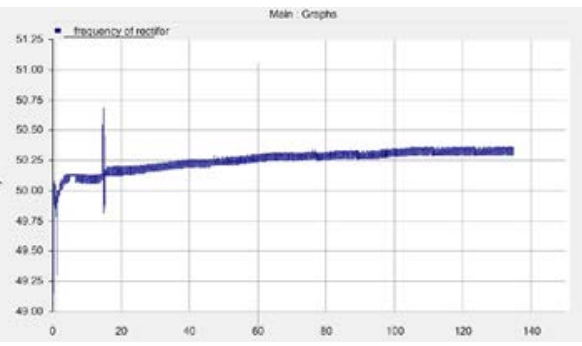

Figure.8. The frequency of the DC power fall 300MW Figure.8. The frequency of the DC power fall 300MW

(2)Result analysis

Under operation of six units/five units/four units, when transmission plan fall 300MW or increase 300MW, the frequency and voltage of sending end system were stable.

TABLE I . THE FREQUENCY OF SENDING END SYSTEM UndeR VARIOUS OPERATING MOdES

\begin{tabular}{|c|c|c|c|c|c|c|c|c|}
\hline No. & $\begin{array}{c}\text { Boot } \\
\text { situation }\end{array}$ & $\begin{array}{c}\text { DC transmission } \\
\text { power/MW }\end{array}$ & $\begin{array}{c}\text { Change of } \\
\text { power/MW }\end{array}$ & $\begin{array}{c}\text { DC Stable } \\
\text { power/MW }\end{array}$ & $\begin{array}{c}\text { Speed of DC } \\
\text { power/MW/m } \\
\text { in }\end{array}$ & $\begin{array}{c}\text { The highest } \\
\text { frequency of } \\
\text { end system } \\
/ \mathrm{Hz}\end{array}$ & $\begin{array}{c}\text { The lowest } \\
\text { frequency of } \\
\text { end system } \\
/ \mathrm{Hz}\end{array}$ & $\begin{array}{c}\text { The stable } \\
\text { frequency of } \\
\text { end } \\
\text { system/Hz }\end{array}$ \\
\hline 1 & 6 generators & 3000 & Fall 300 & 1350 & 200 & 50.345 & 50.054 & 50.29 \\
\hline 2 & 5 generators & 2700 & Fall 300 & 1206.4 & 200 & 50.279 & 50 & 50.2 \\
\hline 3 & 5 generators & 2700 & Increase 300 & 1486 & 200 & 50.644 & 48.596 & 49.751 \\
\hline 4 & 4 generators & 2109 & Increase 300 & 1200 & 200 & 50.238 & 49.647 & 49.8 \\
\hline 5 & 4 generators & 2100 & Fall 300 & 900 & 200 & 50.68 & 49.813 & 50.3 \\
\hline
\end{tabular}

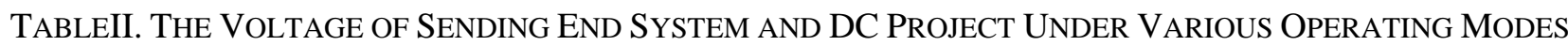

\begin{tabular}{|c|c|c|c|c|c|c|c|c|c|}
\hline No. & Boot situation & $\begin{array}{c}\text { power } \\
\text { of DC } \\
\text { project initi } \\
\text { ally } / \mathrm{MW}\end{array}$ & $\begin{array}{c}\text { Change of } \\
\text { power } \\
\text { /MW }\end{array}$ & $\begin{array}{c}\text { The highest } \\
\text { DC voltage of } \\
\text { end } \\
\text { system/kV }\end{array}$ & $\begin{array}{c}\text { The lowest DC } \\
\text { voltage of end } \\
\text { system } / \mathrm{kV}\end{array}$ & $\begin{array}{c}\text { The stable } \\
\text { DC voltage } \\
\text { of end } \\
\text { system } / \mathrm{kV}\end{array}$ & $\begin{array}{c}\text { The highest } \\
\text { bus voltage } \\
\text { of end } \\
\text { system } / \mathrm{kV}\end{array}$ & $\begin{array}{c}\text { The lowest } \\
\text { bus voltage } \\
\text { of end } \\
\text { system } / \mathrm{kV}\end{array}$ & $\begin{array}{c}\text { The stable } \\
\text { bus voltage } \\
\text { of end } \\
\text { system } / \mathrm{kV}\end{array}$ \\
\hline 1 & 6 generators & 3000 & Fall 300 & 522.25 & 513.808 & 520 & 551.755 & 543.321 & 543.701 \\
\hline 2 & 5 generators & 2700 & Fall 300 & 521.447 & 501.34 & 521.447 & 541.599 & 528.84 & 534.652 \\
\hline 3 & 5 generators & 2700 & $\begin{array}{c}\text { Increase } \\
\text { 300 }\end{array}$ & 518.096 & 480.482 & 495.544 & 531.227 & 523.349 & 524.376 \\
\hline 4 & 4 generators & 2109 & $\begin{array}{c}\text { Increase } \\
300\end{array}$ & 531.2 & 455.5 & 498.5 & 534.36 & 523.26 & 524.236 \\
\hline 5 & 4 generators & 2100 & Fall 300 & 508.239 & 492.77 & 505.5 & 546.827 & 537.274 & 538.681 \\
\hline
\end{tabular}




\section{The System Stability under monopole ESOF of DC project}

\section{A.The control strategy DC power increase/downhill}

If DC transmission power is less than or equal to 1500MW before monopole ESOF, then

(1) If monopole ESOF, the transmission power of the other pole's power increase doubled;

(2) If the sending end system frequency and voltage to meet the requirements, according to the current delivery power operate;

(3) If the sending end system frequency and voltage to don't meet the requirements, according to change of the frequency increase or fall the transmission power. At last, delivery power of ending system reaches the bipolar power delivery; If the frequency and voltage of the sending end system isn't still meet operational requirements, trip generator and set outgoing DC plan; if adopt these measures still cannot meet the frequency and voltage delivery of systems, takes measures of DC blocking.

If the two transmission power is greater than 1500MW before monopole ESOF, then

(1) If monopole ESOF, the transmission power of the other pole increase to $1650 \mathrm{MW}$ and derate output or trip generator according to the actual situation;

(2) If the sending end system frequency and voltage to meet the requirements, according to the current delivery power operate;

(3) If the sending end system frequency and voltage to don't meet the requirements, according change of the frequency increase or fall the transmission power. At last, delivery power of ending system reaches $1650 \mathrm{MW}$; If the frequency and voltage of the sending end system isn't still meet operational requirements, trip generator and set outgoing DC plan; if adopt these measures still cannot meet the frequency and voltage delivery of systems, takes measures of DC blocking.

\section{B.The Research of stability system}

- Operation modes

(1) mode 1: Negative pole block under the six generation units ending end system

The transmission power of DC project was 3000MW. When negative pole blocked, the transmission power of positive pole was 1500MW.

(2) mode 2: Negative pole block and increase outgoing power of DC project to 150MW under the five generation units ending end system

The transmission power of DC project was 2700MW. When negative pole blocked, the transmission power of positive pole increased to 1500MW.

(3) mode 3: Negative pole block and increase outgoing power of DC project to 300MW under the five generation units ending end system

The transmission power of DC project was 2700MW. When negative pole blocked, the transmission power of positive pole increased to 1650MW.

(4) mode 4: Negative pole block and increase outgoing power of DC project to 450MW under the four generation units ending end system

The transmission power of DC project was 2100MW. When negative pole blocked, the transmission power of positive pole increased to 1500MW.

(5) mode 5: Negative pole block and increase outgoing power of DC project to 600MW under the four generation units ending end system

The transmission power of DC project was 2100MW. When negative pole blocked, the transmission power of positive pole increased to 1650MW.

- Result analysis

(1)The result of simulation

The frequency curves of five operation modes above-mentioned were shown in Fig. 9-10. The specific ranges of frequency were shown in Table III. The voltage range of the sending end system and DC project were shown in Table IV. 


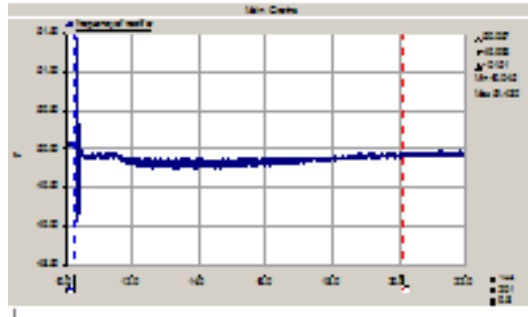

(a) mode 1

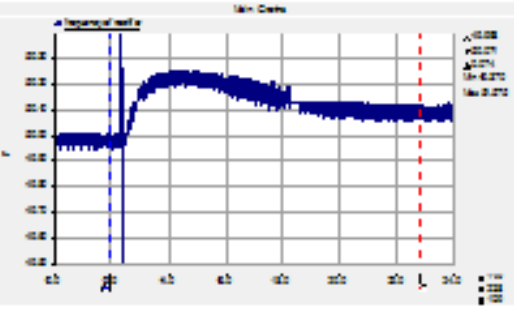

(b) mode 2

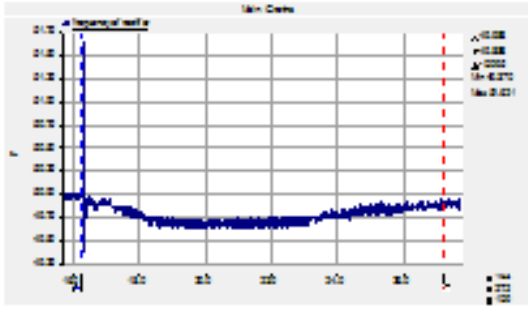

(c)mode3

Figure.9. the frequency of negative pole block of five operation modes

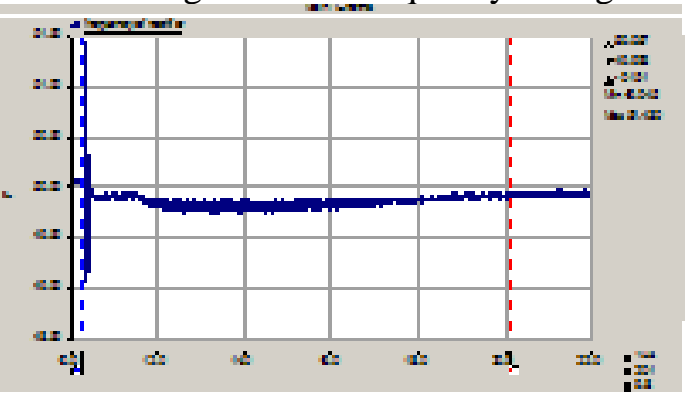

(a) mode 4

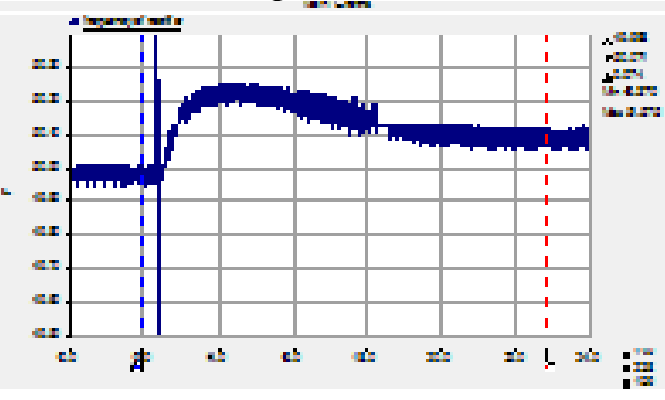

(b) mode 5

Figure.10. the frequency of negative pole block of five operation modes

\section{(2)Result analysis}

Under operation of six units/five units/four units, if negative pole block, when the transmission power of other pole increase $150 \mathrm{MW}$ and $300 \mathrm{MW}$ for five units and the transmission power of other pole increase $450 \mathrm{MW}$ and $600 \mathrm{MW}$ for four units, the frequency can stable at last and the bus voltages can stable.

TABLEIII. THE FREQUENCY OF SENDING END SYSTEM UNDER VARIOUS OPERATING MODES

\begin{tabular}{|c|c|c|c|c|c|c|}
\hline No. & Boot situation & $\begin{array}{c}\text { DC transmission } \\
\text { power/MW }\end{array}$ & $\begin{array}{c}\text { The stable power } \\
\text { of single pole /MW }\end{array}$ & $\begin{array}{c}\text { The highest } \\
\text { frequency of end } \\
\text { system/Hz }\end{array}$ & $\begin{array}{c}\text { The lowest } \\
\text { frequency of end } \\
\text { system } / \mathrm{Hz}\end{array}$ & $\begin{array}{c}\text { The stable frequency } \\
\text { of end system/Hz }\end{array}$ \\
\hline 1 & 6 generators & 3000 & 1500 & 51.43 & 49.117 & 49.892 \\
\hline 2 & 5 generators & 2700 & 1500 & 51.575 & 49.37 & 50.07 \\
\hline 3 & 5 generators & 2700 & 1650 & 51.621 & 49.37 & 49.8 \\
\hline 4 & 4 generators & 2109 & 1500 & 50.083 & 49.63 & 50.15 \\
\hline 5 & 4 generators & 2100 & 1650 & 52.116 & 49.508 & 49.925 \\
\hline
\end{tabular}

TABle IV The Voltage OF SENDING END SySTEM AND DC PROJECT UNDER VARIOUS OPERATING MOdES

\begin{tabular}{|c|c|c|c|c|c|c|c|c|c|}
\hline $\begin{array}{c}\text { No } \\
\cdot\end{array}$ & $\begin{array}{c}\text { Boot } \\
\text { situation }\end{array}$ & $\begin{array}{c}\text { DC } \\
\text { transmission } \\
\text { power/MW }\end{array}$ & $\begin{array}{c}\text { The stable } \\
\text { power of } \\
\text { single pole } \\
\text { /MW }\end{array}$ & $\begin{array}{c}\text { The highest } \\
\text { DC voltage of } \\
\text { end } \\
\text { system/kV }\end{array}$ & $\begin{array}{c}\text { The lowest } \\
\text { end system } \\
\text { enV }\end{array}$ & $\begin{array}{c}\text { The stable } \\
\text { DC voltage of bus voltage of bus voltage of } \\
\text { end system } \\
\text { /kV }\end{array}$ & $\begin{array}{c}\text { The highest } \\
\text { end system } \\
\text { /kV }\end{array}$ & $\begin{array}{c}\text { The stable bus } \\
\text { end system } \\
\text { /kV }\end{array}$ & $\begin{array}{c}\text { voltage of end } \\
\text { system /kV }\end{array}$ \\
\hline 1 & 6 generators & 3000 & 1500 & 644.981 & 438.068 & 510 & 633.829 & 536.94 & 570 \\
\hline 2 & 5 generators & 2700 & 1500 & 631.491 & 464.423 & 506.628 & 613.304 & 530.855 & 554.033 \\
\hline 3 & 5 generators & 2700 & 1650 & 629.601 & 464.355 & 505.576 & 595.289 & 531.389 & 543.168 \\
\hline 4 & 4 generators & 2109 & 1500 & 636.536 & 447.75 & 487.1 & 600.04 & 541.239 & 550 \\
\hline 5 & 4 generators & 2100 & 1650 & 637.245 & 448.379 & 487.3 & 595.304 & 525.851 & 549 \\
\hline
\end{tabular}




\section{The System Stability After Generator Tripping Because of Ending System Units Fault}

\section{A.The control strategy DC power downhill}

Trip generator by 10 cycles after fault, and decrease power DC power delivery according to the capacity of generator tripping. If frequency and voltage of the sending end system meet the requirements, operate according to the current delivery of power. If the frequency and voltage of sending end system does not meet the requirements, increase or fall the transmission power according change of the frequency. If adopt these measures still cannot meet the frequency and voltage delivery of systems, takes measures of tripping generator DC blocking.

\section{B.The System Stability after generator tripping because of ending system units fault}

- Operation modes

(1) A generator tripping because units fault in six generator system

The DC transmission power is 3000MW. Trip a generator of Baorixile plant, DC transmission power fall by $1000 \mathrm{MW} / \mathrm{s}$ and single pole outgoing power from 1500MW to 1200MW.

(2) A generator tripping because units fault in five generator system

The DC transmission power is 2700MW. Trip a generator of Baorixile plant, DC transmission power fall by $1000 \mathrm{MW} / \mathrm{s}$ and single pole outgoing power from 1350MW to 1050MW.

(3) A generator tripping because units fault in four generator system

The DC transmission power is 2100MW. Trip a generator of Ewenke plant, DC transmission power fall by $1050 \mathrm{MW} / \mathrm{s}$ and single pole outgoing power from $1500 \mathrm{MW}$ to $750 \mathrm{MW}$.

- Result analysis

(1)The result of simulation

The frequency curves of three operation modes above-mentioned were shown in Fig. 11. The specific ranges of frequency were shown in Table $\mathrm{V}$. The voltage range of the sending end system and DC project were shown in Table VI.

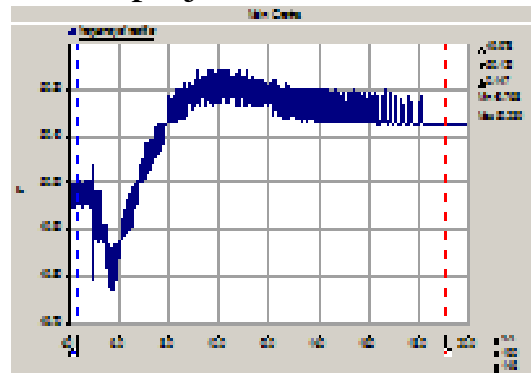

(a) under six units

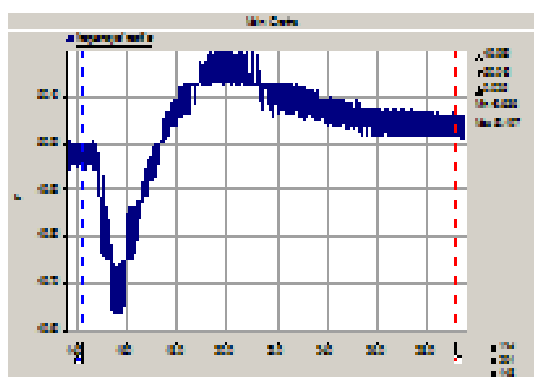

(b) under five units

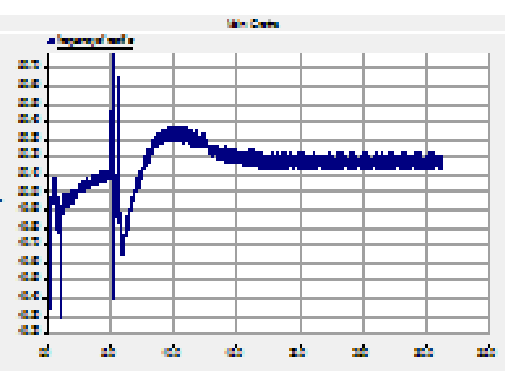

(c) under four units

Figure 11. The frequency of a generator tripping

\section{(2)Result analysis}

Under operation of six units/five units/four units, trip generator by 10 cycles after fault, and decrease power DC power delivery by $1000 \mathrm{WM} / \mathrm{s}$ according to the capacity of generator tripping. According to the results, the frequency and voltage of sending end system were stable.

TABLE V THE FREQUENCY OF SENDING END SYSTEM OF A GENERATOR TRIPPING UNDER VARIOUS OPERATING MODES

\begin{tabular}{|c|c|c|c|c|c|c|c|}
\hline No. & Boot situation & $\begin{array}{c}\text { DC transmission } \\
\text { power/MW }\end{array}$ & $\begin{array}{c}\text { The stable } \\
\text { power of single } \\
\text { pole } / \mathrm{MW}\end{array}$ & $\begin{array}{c}\text { The frequency of } \\
\text { end } \\
\text { system initially/Hz }\end{array}$ & $\begin{array}{c}\text { The highest } \\
\text { frequency of end } \\
\text { system/Hz }\end{array}$ & $\begin{array}{c}\text { The lowest } \\
\text { frequency of end } \\
\text { system /Hz }\end{array}$ & $\begin{array}{c}\text { The stable } \\
\text { frequency of end } \\
\text { system/Hz }\end{array}$ \\
\hline 1 & 6 generators & 3000 & 2400 & 49.98 & 50.239 & 49.768 & 50.125 \\
\hline 2 & 5 generators & 2700 & 2100 & 49.98 & 50.197 & 49.636 & 50.015 \\
\hline 3 & 4 generators & 2109 & 1500 & 50.08 & 50.364 & 49.641 & 40.175 \\
\hline
\end{tabular}


TABLE VI The Voltage Of SENDING END System AND DC PROJECT OF A GENERATOR TRIPPING UNDER VARIOUS OPERATING MODES

\begin{tabular}{|c|c|c|c|c|c|c|c|c|c|c|}
\hline No & $\begin{array}{c}\text { Boot } \\
\text { situation }\end{array}$ & $\begin{array}{c}\text { DC } \\
\text { transmissio } \\
\mathrm{n} \\
\text { power/MW }\end{array}$ & $\begin{array}{c}\text { The stable } \\
\text { power of } \\
\text { single pole } \\
\text { /MW }\end{array}$ & $\begin{array}{c}\text { The DC } \\
\text { voltage } \\
\text { before } \\
\text { blocking/kV }\end{array}$ & $\begin{array}{c}\text { The highest } \\
\text { DC after } \\
\text { blocking } \\
\text { /kV }\end{array}$ & $\begin{array}{c}\text { The } \\
\text { lowest DC } \\
\text { after } \\
\text { blocking } \\
/ \mathrm{kV}\end{array}$ & $\begin{array}{c}\text { The stable } \\
\text { DC after } \\
\text { blocking } \\
/ \mathrm{kV}\end{array}$ & $\begin{array}{c}\text { The highest } \\
\text { bus voltage } \\
\text { of end } \\
\text { system } / \mathrm{kV}\end{array}$ & $\begin{array}{c}\text { The lowest } \\
\text { bus voltage } \\
\text { of end } \\
\text { system } / \mathrm{kV}\end{array}$ & $\begin{array}{c}\text { The stable } \\
\text { bus voltage } \\
\text { of end } \\
\text { system } / \mathrm{kV}\end{array}$ \\
\hline 1 & 6 generators & 3000 & 2400 & 515 & 516.582 & 485.23 & 510 & 553.582 & 507.471 & 538.776 \\
\hline 2 & 5 generators & 2700 & 2100 & 504 & 524.188 & 488.271 & 516 & 558.853 & 514.286 & 545.716 \\
\hline 3 & 4 generators & 2109 & 1500 & 510 & 514.716 & 468.353 & 510 & 575.408 & 501.869 & 555 \\
\hline
\end{tabular}

\section{Conclusion}

Under the operation modes the Hu-liao DC sending end system as described in the paper, after the change of the DC plan external-transmission, DC project occur monopole ESOF and the sending-end occur three-phase short circuit fault, the coordinated control strategy of DC Engineering and islands sending end system can meet the system frequency, voltage and DC power transmission requirements. In this paper, the control strategy can provide a reference for the power dispatching and production department.

\section{References}

[1] Yuan Qing-yun. Development Planning and Research Accomplishments of UHVDC Transmission in China. Electrical Equipment [J], 2007 8(3) 1-4.

[2] Zeng Nanchao. Role of HVDC Transmission in the Power System Development in China. High Voltage Engineering [J], 200430 (11) 11-12.

[3] Yuan Qing-yun. Present State and Application Prospect of UHVDC Transmission in China. Power System Technology [J], 200529 (14) 1-3.

[4] Shu Yinbiao. Present Status and Prospect of HVDC Transmission in China. High Voltage Engineering[J], 200430 (11) 12-20.

[5] Ma Yu-long, Shi Yan, Yin Wei-yang and Yang Zhi-dong. Additional Control Strategy for Islanded AC System at Sending Terminal of HVDC. Power System Technology [J], 200630 (24) 22-25.

[6] Wang Hua-wei, Zeng Nan-chao, Jiang Wei-ping, Wu Ya-ni, Zhao Liang, ect. Study on Minimal Startup Power of $\pm 660 \mathrm{kV}$ HVDC Power Transmission System Under Islanded Operation at Sending System. Power System Technology [J], 201034 (5) 83-87.

[7] Wu Xiaochen, Jin Xiaoming, Zhao Yong, Zhou Baorong, Xu Aidong and Chen Jianbin. On Stability of Islanded Operation of Yunnan-Guangdong UHVDC Project Soutch Electic Power Technoloty Power Technology [J], 20104 (1) 7-12.

[8] Zhao Liang, Qin Qin, Guo Qiang, Guo Xiao-jiang, Wang Hua-wei and Zhang Ke. Frequency Control for Islanded System at Sending Terminal of HVDC Power Transmission from China to Mongolia. Power System Technology [J], 200832 (21) 22-25.

[9] Li Ya-nan,Ma Wei-min,Yin Wei-yang,Liu Bao-hong,Fan Ji-chao. Island Operation Modes XS800 UHVDC System. High Voltage Engineering [J], 201036 (1) 185-189.

[10] Y.D. SONG, Q. ZHANG. The Simulation Model for Research of Island Operation Control Strategy in HVDC Weak Sending-end System. ICMET 2004[C], Hainan: Sanyan, 2014. 583-590. 